\title{
Kartu Prakerja (Pre-Employment Card) Policy and Its Impact on Economy and Community Income
}

\begin{abstract}
${ }^{1}$ Suryadia, Emi Syarif ${ }^{\text {b }}$ Yuniarti Tri Suwadjic, Ardhian Kurniawatid, Hennigusnia ${ }^{e}$ Ivan Lilin Suryonof, Beni Teguh Gunawang, Nurlia Rahmatika $^{h}$, Faizal Amir P. Nasution, Nur Siti Annazah', Zelius Ragilliawan $^{\mathrm{k}}$, Firdausi Nuzulal, a,b,c,d,e,f,g,h,i,j,k,l Policy Development Center, Ministry of Manpower, Email: ${ }^{\mathrm{a}}$ suryadi.value@gmail.com, bemi.elmyanda@gmail.com, cyuniartits85@gmail.com, ddheant85@gmail.com, `henigusnia@alumni.ui.ac.id, , $^{\mathrm{iv}}$ @anlilins@gmail.com, ${ }^{\mathrm{g}}$ beni.teguhg@ gmail.com, htiikaa.fad@gmail.com, ifaiz10march@gmail.com, janazah.siti@gmail.com, kzellius.ragiliawan@gmail.com, $\underline{\text { iirdausinuzula.02225@gmail.com }}$
\end{abstract}

This Kartu Prakerja (Pre-Employment Card) Policy Study aims to analyze the impact of the government's 2021 budget allocation of IDR 30 Trillion (US\$ 2.065 billion) on the Indonesian economy and the increasing of community income, as well as the benefits and drawbacks of implementing the pre-employment card program. The novelty of this study is regarding to its study ability to find solutions for quantitative government budget allocation policies in the context of policy making. The results show that the government's budget allocation for the Pre-Employment Card Program is able to increase Indonesia's Economic Growth by 0.23 percent and community income by 0.53 percent.

Key words: Pre-Employment Card, Economic Growth, Community Income

\section{Introduction}

Indonesia is one of the countries affected by COVID-19 virus and is one of the countries that contribute to the highest death rate in the world. One of the characteristics of the Covid-19 disease is that it is easily contagious, so that it can quickly infects many people. Indonesia has tried to take action to reduce the spread of COVID-19 virus through non-medical measures, for instance by enforcing work holidays, cancelling large gatherings, restricting business trip, and many others.

\footnotetext{
${ }^{1}$ All the writers are main contributors.
} 
There are some policies taken by the government in controlling the spread of Covid-19. First, it is began with the enactment of a lockdown policy on March 20, 2020. Lockdown is a policy of closing access in an area, both access to enter and access to exit from such an area. When an area has been imposed with a lockdown, people living in that area may not be go outside the area and are also not allowed to do outdoor activities. Lockdown in Indonesia causes people to be unable to carry out activities outside the home as usual. In addition, activities outside the home are also enforced during the lockdown by prohibiting gatherings with large numbers of people in offices, schools, or places of worship as well as in other public places. This lockdown policy is implemented in order to minimize the risk of virus transmitting, and it is only applied temporarily. If there is a better condition, then the government can take out this policy.

The next policy is the implementation of Large-Scale Social Restrictions (PSBB/Pembatasan Sosial Berskala Besar) which have been in effect since March 31, 2020 through Government Regulation Number 21 of 2020. The implementation of PSBB has not been applied evenly in all regions in Indonesia due to certain conditions that should be fulfill to implement PSBB. DKI Jakarta becomes the first province which implemented PSBB because this area was the epicenter of the spread of COVID-19 virus in Indonesia. After DKI Jakarta, other five regions in West Java that are neighbors to DKI Jakarta have implemented PSBB, such as Bogor Regency, Bogor City, Depok City, Bekasi Regency, and Bekasi City since April 15, 2020. Furthermore, three areas in Banten Province were also imposed with PSBB, namely Tangerang City, Tangerang Regency, and South Tangerang City. Other areas that have implemented PSBB are Pekanbaru City in Riau Province, and Makassar City in South Sulawesi Province which becomes the first city in Sulawesi Island implemented PSBB. Greater Bandung then becomes the next area in West Java Province decided to implement PSBB. There are five areas in Greater Bandung where the PSBB will be applied, including Bandung City, Bandung Regency, West Bandung Regency, Cimahi City, and Sumedang Regency. Tegal City then becomes the first area in Central Java which receive a permit to carry out PSBB. Last but not least, West Sumatera became the second province to be approved for implementing the PSBB.

After PSBB, the next policy implemented by the government is the Policy for Enforcement of Community Activity Restrictions (PPKM/Pemberlakuan Pembatasan Kegiatan Masyarakat). The PPKM policy is carried out to limit interactions, small group meetings, and large group meetings which are expected to reduce the transmission of COVID-19. The PPKM policy was first implemented on January 11 - January 25, 2021, covering the DKI Jakarta area and other 23 regencies/cities in six provinces that are high risk areas for the spread of COVID-19. Furthermore, on February 9 - 22 2021, PPKM Mikro is set to apply in 7 provinces with more complete rules based on zoning, and was starting from the lowest level of government in each district, namely at the Neighborhood Association/Citizens Association (RT/RW or Rukun Warga/Rukun Tetangga) level. Furthermore, in early July 2021, the government re-enacted the provision of Emergency PPKM (PPKM/Pemberlakuan Pembatasan Kegiatan Masyarakat Darurat). Government choose this policy because of the appearance of new COVID-19 cases 
caused by a new virus variant. Emergency PPKM is effective from 3-20 July 2021, especially in Java and Bali Islands. However, along with the increasing number of cases, Emergency PPKM was also expanded to 15 regions outside Java and Bali Islands.

The impact of these policies are there are many people who lose their income, especially for those who have low incomes. The compensation of all those policies carried out by the Government is by launching a social assistance program that is given to low-income communities. This social assistance is provided in various forms, such as Pre-Employment Card (Kartu Prakerja) Program, direct cash assistance, reduction of electricity costs for certain groups, provision of basic needs assistance and many others. By providing social assistance, it will greatly help the community when economic uncertainty occurs because of the weakening economy.

The Pre-Employment Card (Kartu Prakerja) Program is one of the government's programs to support the Indonesian economy development. The government decided to accelerate the process of realizing its distribution and procurement of the Pre-Employment Card Program faster than the initial plan because of the many layoffs cases that occur everywhere due to the COVID-19 pandemic in many regions in Indonesia. To continue running this program, the Minister of Finance then allocated a budget of IDR 30 Trillion (US\$2.065 billion) in 2021. This is a follow-up to the result of a survey which found that the Pre-Employment Card program has proven to help the job seekers or those affected by layoffs during the COVID-19 pandemic.

Participants who register for this Pre-Employment Card will each receive IDR 3,550,000 (US\$ 244.74) during the program. In details, the intensive assistance are consist of online skills training costs as much IDR 1,000,000 (US\$ 68.96) which cannot be disbursed, incentives after successfully completing the online skills training as much IDR 600,000 (US\$41.38) per month for 4 months training program, and incentive funds to fill out its training evaluation survey as much IDR 150,000 (US\$ 10.34). Therefore, they who utilize the pre-employment card will receive funding for skills training (ability), upskilling (capability enhancement), and re-skilling (capability replacement).

This research aims to:

a. Analyzing the impact of the government's budget allocation of 2021 for the PreEmployment Card (Kartu Prakerja) Program as much IDR 30 Trillion (US\$ 2.065 billion) on the Indonesian economy;

b. Analyzing the impact of the government's budget allocation of 2021 for the PreEmployment Card (Kartu Prakerja) Program as much IDR 30 Trillion (US\$ 2.065 billion) on increasing community income;

c. Analyzing the benefits of pre-employment cards and its weaknesses in the implementation of the Pre-Employment Card Program. 


\section{Literature Review}

Governments in around the world have introduced many regulations in restricting mobility and social interaction with the primary aim of limiting the spread of COVID-19. However, the policy is expected to lead to a decline in livelihoods through its impact on the labor market, especially for low-income individuals and households (Köhler and Bhorat, 2020). The labor market is impacted on low-income households. Fiscal policy in the form of additional government spending due to the pandemic has brought benefits to poor households. The expansion of the social assistance system is not only a critical action by the government, but also it is monitored to ensure that the policy is on target.

Many studies regarding to the impact of COVID-19 pandemic on the socio-economic conditions of the community have been carried out, including in Indonesia. Most of these studies cover the Indonesian government's socio-economic policy strategy in overcoming various phenomena due to the COVID-19 pandemic. Nugroho and Azmi (2021); Muhafidin (2021); Sparrow et al. (2020); Roziqin et al. (2021); Israhadi (2020); Sumarto and Ferdiansyah (2021); Hendrianto (2020); Hidayat et al. (2021)) using a qualitative descriptive method conduct some studies generally focus on social protection policies, and how to implement them in society. The results of the study show that the Indonesian government has several programs as a COVID-19 safety net, namely the Family Hope Program (Program Keluarga Harapan/PKH), Basic Food Cards/Kartu Sembako, Cash Intensive Work (Padat Karya Tunai /PKT), Direct Cash Assistance (Bantuan Langsung Tunai/BLT), Bulog Rice Assistance Program/Program Bantuan Beras Bulog, Social Assistance Cash (Bantuan Sosial Tunai /BST), Electricity Subsidy, Pre-Employment Card/Kartu Prakerja, Internet Quota Subsidy and Village Fund Direct Cash Assistance (Bantuan Langsung Tunai Dana Desa/BLT-DD). However, those policies are only focused on short-term recovery. In addition, at the level of implementation, the social protection policy is still not distributed appropriately according to the provisions, for example unequal distribution of aid, uncertainty of procedures and requirements for receiving aid, and so on.

The Pre-Employment Card Program is one of the efforts to restore the economy especially for people affected by the COVID-19 pandemic. Kurnianingsih et al. (2020) stated that the PreEmployment Card Program carries out two missions, namely the mission to improve the workforce competence and the mission to increase people purchasing power affected by the COVID-19 pandemic. The Pre-Employment Card Program launched by the Indonesian government aims to assist job seekers in improving their skills according to the skills needed in the current job market (Halimatussadiah et al., 2020).

In the Pre-Employment Card Program, people who do not have jobs and wish to receive job training will get both fees and job training. Furthermore, people who will entry to work perhaps will be more competent, have expertise in their work field and of course will increase the 
human resources competence in Indonesia (Zubaidia et al., 2020). However, in its implementation, the results of the study of Kurnianingsih et al. (2020) stated that social protection in the Pre-Employment Card Program has not shown the improving impact of improving and changing the economy of small, medium, and even large companies. Therefore, Predianto and Khoirurrosyid (2020) and Kurnianingsih et al. (2020) in their study suggested that the Indonesian government has already evaluate by taking strategic and regulatory steps. These strategic and regulatory steps is taken into account by changing an innovation in the PreEmployment Card Program as a long-term priority scale, to avoid gaps in implementing social protection policies process that will create some adversely affects to the Indonesian welfare.

According to Lord (2020), the government must quickly find tools to deal with the economic and health crisis in the current state. The government needs both to control and to ensure that program benefits really target those needed. So that, they are not distorted. Abdoul-Azize and Gamil (2020), revealed that although the country's socio-economic conditions had decreased, the Social Protection Program had become a strategic tool in dealing with the COVID-19 pandemic. Most high-income countries such as Spain, Italy, Germany, the UK and Chile are focusing on implementing Social Protection Programs to stabilize the macroeconomic impact of the COVID-19 pandemic; while upper-middle- and lower-middle-income countries such as Turkey, Peru, Brazil, India and Pakistan are focusing on implementing Social Protection Programs to improve the living conditions of the poor and vulnerable during the pandemic crisis. However, according to Lu et al. (2020), it is important to ensure the programs that cover more than one area of social policy and require much more coordinated policy interventions from various policies, including economic policy, employment policy, fiscal policy and social policy.

There are some adverse effects of the COVID-19 pandemic. For instance, it can increase our health risks, disrupts of production process and agricultural products marketing, increases the burden of health spending, and reduces access to education and training which can decreases labor productivity in the agricultural sector (Abidin, 2021). The more COVID-19 cases in Indonesia, the higher number of small, medium and large companies that getting bankrupt. Furthermore, there are several regulations related to labor that are implemented by the government. These regulations are certainly expected to protect workers from being terminated. One of these regulations is the Pre-Employment Card to create new jobs, so that workers can live their lives (Al-Fatih et al., 2020).

The government has taken various steps both at the central and regional levels to prevent the spread of the corona virus from getting worse (Andriani, 2020). The fiscal policy implemented by the government reacted quickly in the face of economic shocks by increasing health and livelihood spending. One of the fiscal mitigation measures that have been implemented is taken for giving social protection (World Bank, 2020). Analysis of Gerard et al. (2020) highlighting that governments in developing countries, it is a must to find some creative solutions in order 
to build a comprehensive social protection response in facing the economic impact of the COVID-19 pandemic that could be happen. Existing job retention programs in some countries for examples, could be used more broadly to protect jobs in the formal sector.

Many countries have implemented some policies regarding to direct transfer program's scheme. These programs are targeted the beneficiaries precisely by identifying which one is categorized as the poor, and then also limiting its transfers to these kind of individuals (Hanna and Olken, 2018). Based on research conducted by Hidayat et al. (2021), in the micro, small and medium enterprise (MSME) sector in Indonesia, the COVID-19 pandemic has had an impact on creating lower sales rate, capital difficulties, product distribution barriers, and difficulties in meeting raw materials. There some policies that can be issued by the government, for instance: by giving social assistance to the poor and vulnerable MSMEs; tax incentives for MSMEs; relaxation and credit restructuring for MSMEs; expansion of working capital financing; and e-learning training. To support these government policies, there are several short-term and long-term strategies need to be considered by the government in order to encourage government-corporate cooperation in empowering MSMEs.

Several countries, especially in East Asia, are currently strengthening labor market programs, especially in terms of brokerage services and skills training. This is happening in China, Indonesia, Malaysia, and the Philippines. The International Labor Organization (2021) states that Indonesia has increased its budget allocation for the Pre-Employment Card Program, which provides subsidized vouchers for unemployed workers to improve job skills. This program can be accessed by around 5.6 million informal workers and micro and small businesses affected by COVID-19 pandemic.

The spread of the Corona Virus has caused several industries and entrepreneurs to suffer losses due to a decrease in production (Ivanka, 2021). Therefore, many companies lay-off their workers. Termination of employment for reasons of efficiency allows the company to permanently close its business (Mahy, 2020). Severance pay must still be provided to workers affected by its employment termination. To face this condition, furthermore, The Indonesian Government has issued a Pre-Employment Card policy that can be gained by the workers who have lost their jobs. The purpose of this Pre-Employment Card is to increase both of workers' skills and knowledge; thus, they can be ready to re-enter the labor market.

The purpose of handling COVID-19 in Indonesia can create different interests between the government and politicians. It is because politicians seem to more focus on economic gain. However, The Pre-Employment Card is considered to be very beneficial for platform companies that collaborate with the government in providing job training (Masduki, 2020). It is considered to the situation that workers can find it difficult to find a job if they only rely on themselves. Therefore, they have to get some assistance in order to help them to find good jobs 
that provide wage incentives and other rights, such as benefits and wages above the minimum wage (Michalopoulos, 2001).

There are various programs and activities which have been carried out by the government in dealing with the COVID-19 pandemic, either in developing or industrialized countries. Developing countries usually have countries' characteristics with low production level, low education level, poor infrastructure, low living standard, low capital income, and limited access to health protection; whilst industrialized countries usually have countries' characteristics with high economic level, high per capita income, income equality, high living standard, high industrialization, and proper infrastructure. Tedjakusuma and Rudenko (2021) prove that there are differences in policies in Indonesia as a developing country and Slovakia as an industrial country. All in all, The Pre-Employment Card Program is such a government's flagship program for all workers, employers, and employment termination victims containing assistance for training costs according to their respective talents and interests (Vaziralli, 2021).

\section{Research Methods}

To estimate the impact of Pre-Employment Card (Kartu Prakerja) policy, this study is utilizing the Social Accounting Matrix (SAM) of 2008 as a matrix that summarizes the overall social and economic balance. The SAM framework can be used to estimate the effects of exogenous changes and injections into the economy. Each injection in the SAM will be transmitted through a system of interrelated socioeconomic accounts. Next, the effect of the injection on the endogenous balance will be estimated through a multiplier process. For the purposes of multiplier analysis, the endogenous balance sheet from the transaction matrix is converted to a coefficient matrix (proportion of average expenditure). This can simply be obtained by dividing the endogenous balance sheet element by the total income of each column in which the element is located.

\section{SAM Multiplier Analysis Framework}

The multiplier analysis in the SAM model can be divided into two major groups, namely the accounting multiplier and the fixed price multiplier. The accounting multiplier analysis is basically the same as the multiplier from the Leontief Inverse Matrix contained in the I-O model. Meanwhile, the fixed price multiplier analysis leads to an analysis of household responses to changes in the exogenous balance by taking into account the expenditure propensity.

Furthermore, if it is assumed that the average trend of $\mathrm{A}_{\mathrm{ij}}$ expenditure which is the comparison between the expenditure of the jth sector for the $\mathrm{i}$-sector and the $\mathrm{j}$-total expenditure $(\mathrm{Yj})$, then the equation is as follows:

$\mathrm{I}=\mathrm{A}+\mathrm{X} / \mathrm{Y}$

$\mathrm{I}-\mathrm{A}=\mathrm{X} / \mathrm{Y}$ 
$(\mathrm{I}-\mathrm{A}) \mathrm{Y}=\mathrm{X}$

$\mathrm{Y}=(\mathrm{I}-\mathrm{A})-1 \mathrm{X}$

If $\mathrm{Ma}=(\mathrm{I}-\mathrm{A})-1$ then $\mathrm{Y}=\mathrm{Ma} \mathrm{X}$

Where $\mathrm{A}$ is a coefficient that shows the direct effect of changes which occur in one sector on other sectors. The Ma matrix is a balance multiplier that shows the effect of a sector on another sector of the entire MAS. Matrix X shows the exogenous balance.

\section{Assumptions in the Pre-Employment Card Impact Study}

This study uses several assumptions in simulating the impact of the pre-employment card budget allocation on the economy and increasing people's income. The assumptions are:

a. Budget allocations for pre-employment card program are given to Urban Households and the Education Services Sector;

b. The budget for the pre-employment card program will increase economic growth and people's income through the created multiplier;

c. The inflation rate is assumed to be 3 percent, Indonesia's economic growth is 4.5 percent and household consumption growth is 4 percent in 2021.

\section{Simulation Scenario}

This study uses a simulation of the value of the budget allocation issued by the government for pre-employment cards program in 2021 of IDR 30 Trillion (US $\$ 2.065$ billion), with details of IDR 20.2 trillion for transfer allocations to low-income households in cities and IDR 9.8 Trillion for educational services in the form of job training.

\section{Results and Discussion}

1. Economic Growth from the Budget Allocation of IDR 30 Trillion in 2021

The pre-employment card is expected to have a significant impact on certain sectors of the economy. Based on Table 1, it can be seen that the provision of assistance through this mechanism has the highest impact on the Government Services Sector at 0.72 percent. The next six sectors most affected by the pre-employment card assistance are the Food Crops Sector (0.67 percent), Restaurant Sector (0.41 percent), Livestock Sector (0.37 percent), Other Services Sector ( 0.36 percent), Fishery Sector ( 0.28 percent) and Electricity-Gas-Water Sector (0.28 percent). On the other hand, the Pre-Employment Card Policy also has very little impact on certain sectors. The mining sector excluding coal and oil only grew 0.03 percent due to the 
pre-employment card policy. Likewise, the construction sector grew by only 0.01 percent even though the Pre-Employment Card budget was realized at 100 percent.

These results indicate that the Pre-Employment Card policy can be used as an alternative to increase economic growth. Based on Table 1, the overall impact on national economic growth is 0.23 percent. During the Covid-19 pandemic, economic growth is an important indicator of the government's success. The total budget for pre-employment cards of Rp. 30 trillion is considered capable of providing an adequate trade-off from an economic perspective. However, if viewed from its main purpose as a safety net instrument for workers due to Covid19, the Pre-Employment Card Policy has an anomalous impact on the employment side. For example, among several sectors with the greatest impact, there are government services, restaurants and other services which are sectors that can be categorized as not absorbing too many workers. On the other hand, the construction and mining sectors, excluding coal or oil, which absorb a large number of workers, have little growth.

However, overall, the pre-employment card can be categorized as a reliable policy. In terms of the economy, the government needs the right instruments to keep economic growth from contracting due to the pandemic. In terms of employment, economic growth despite an anomalous impact on employment is still worthy of consideration. 
International Journal of Innovation, Creativity and Change. www.ijicc.net

Volume 15, Issue 10, 2021

Table 1. Sectoral Economic Growth from the Pre-Employment Card Budget Allocation

\begin{tabular}{|c|l|l|}
\hline No. & \multicolumn{1}{|c|}{ Economic Sector } & Percent \\
\hline 1. & Food Crops & 0.67 \\
\hline 2. & Other Crops & 0.13 \\
\hline 3. & Livestock & 0.37 \\
\hline 4. & Forestry & 0.09 \\
\hline 5. & Fishery & 0.28 \\
\hline 6. & Coal-Ore Oil Mining & 0.12 \\
\hline 7. & Other Mining & 0.03 \\
\hline 8. & Food-Beverage-Tobacco & 0.20 \\
\hline 9. & Textiles & 0.19 \\
\hline 10. & Woods & 0.12 \\
\hline 11. & Papers-Equipment & 0.16 \\
\hline 12. & Chemicals & 0.22 \\
\hline 13 & Electricity-Gas-Water & 0.28 \\
\hline 14. & Constructions & 0.01 \\
\hline 15. & Restaurant & 0.41 \\
\hline 16. & Hotels & 0.08 \\
\hline 17. & Road Transportation & 0.12 \\
\hline 18. & Air-Water Transportation & 0.13 \\
\hline 19. & Transportation Supports & 0.07 \\
\hline 20. & Bank-Finance & 0.14 \\
\hline 21. & Real Estate & 0.17 \\
\hline 22. & Government Services & 0.72 \\
\hline 23. & Other Services & 0.36 \\
\hline & National Economic Growth & 0.23 \\
\hline
\end{tabular}

Source: Data Processed From Social Accounting Matrix

Governments need to find creative solutions to build a comprehensive social protection response to the economic impact of the COVID-19 epidemic. An existing job retention program in a country such as Brazil, for example, can serve as a lesson for wider use in protecting jobs in the formal and informal sectors. The challenge of mitigating the economic impact of this pandemic is enormous. The speed of overcoming solutions is very necessary, any solution will be of less benefit if it is not carried out quickly to overcome the decline in performance in the economy due to Covid-19.

Indonesia needs financial support both internally and externally to create economic space for an effective response. A policy coalition strategy between the central and local governments is indispensable in influencing the process of establishing social safety net policies. In terms of the Covid-19 safety net program, at least the government has had several programs as a Covid19 safety net, namely the Family Hope Program (PKH), Basic Food Cards, Cash Intensive Work (PKT), Direct Cash Assistance (BLT), Basic Food Cards, Program Bulog Rice Assistance, Cash Social Assistance (BST), Electricity Subsidy, Pre-Employment Card, Internet Quota Subsidy and Village Fund Direct Cash Assistance (BLT-DD). 
The orientation towards economic flexibility in the midst of the Covid-19 pandemic can be done when the government systematically and consistently implements the Pre-Employment Card Program that can be reviewed from allocation policies, distribution policies, and stabilization policies.

The three policies must be supported by concrete formulations and strategies that follow empirical conditions. The government has developed an economic recovery plan that concentrates on protecting the short-term effects of the crisis and supporting the poor and nearpoor, rather than reducing long-term poverty and preventing structural changes in unemployment.

It was found that Indonesia's social policy response to the pandemic was primarily through the reallocation of government budgets to finance targeted social safety net programs that included social assistance, family support, and labor market benefits (Pre-Employment Cards, Wage Subsidies, and Productive Assistance for Micro Enterprises). Although some of these social security are urgently needed, the government prefers to prioritize labor market benefits to support economic productivity. However, this budget reallocation was not sufficient to cover all the poor, so the government sought financial support from the World Bank, global bonds, and local governments.

The purpose of implementing social protection policies made by the Indonesian government in the Pre-Employment Card Program is to be able to provide support for the welfare of the community in increasing competence to create new jobs. However, the process of implementing social protection policies in the Pre-Employment Card Program has not shown the impact of improvements and economic or social changes during the COVID-19 pandemic that the community expects. The maximum goal is not achieved, due to the stipulation of social protection policies that are not used in an emergency. In addition, the perpetrators of the PreEmployment Card Program have different interests and goals, both from the implementing party and the recipient party.

The Indonesian government must evaluate and take strategic steps and regulations on the PreEmployment Card Program as a priority scale to avoid gaps in the process of implementing social protection policies that will adversely affect the welfare of the Indonesian people. There needs to be a more in-depth study of the management of the Pre-Employment Card Program on program orientation, program innovation and program design. The Indonesian government must carry out a mentoring process by establishing a Job Creation Supervisory Agency that will pay attention to social protection policies in the Pre-Employment Card Program. The formation of the Supervisory Board the Job Creation Committee has a control function in anticipating and overcoming violations that occur in social protection policies in the PreEmployment Card Program which will continue in the future. 
2. Community Income Growth from Budget Allocation of IDR 30 Trillion in 2021

The unprecedented Covid-19 crisis has prompted strict government intervention in the areas of income and people's welfare. The government needs to pay attention to the welfare of millions of people who have suffered directly or indirectly from the negative impacts caused by Covid19. Many countries implement their fiscal policies through government transfers to provide financial support to the poor, vulnerable groups and economic sectors that are directly or indirectly affected by the COVID-19 pandemic. These programs include employment protection such as the Pre-Employment Card Program, Wage Subsidies for the poor and vulnerable groups to increase their resilience in facing the challenges posed by the COVID-19 pandemic.

Table 2. Community Income Growth from the Pre-Employment Card Budget Allocation

\begin{tabular}{|l|l|c|}
\hline No. & \multicolumn{1}{|c|}{ Household Sector } & Percent \\
\hline 1. & Agric Workers & 0.02 \\
\hline 2. & Agric Employers & 0.07 \\
\hline 3. & Non-Agric Rural Low & 0.03 \\
\hline 4. & Non-Agric Rural Others & 0.02 \\
\hline 5. & Non-Agric Rural High & 0.05 \\
\hline 6. & Non-Agric Urban Low & 0.27 \\
\hline 7. & Non-Agric Urban Others & 0.02 \\
\hline 8. & Non-Agric Urban High & 0.07 \\
\hline
\end{tabular}

Source: Data Processed From Social Accounting Matrix

The results of the analysis using the Social Accounting Matrix (SAM) show that government assistance through the Pre-Employment Card Program has more impact in urban areas than in rural areas. The data in Table 2 shows the sectors in urban areas that experienced a large increase in income. The impact in urban areas is mostly enjoyed by those with high incomes, such as Non-Agric Urban Low 0.27 percent and Non-Agric Urban High 0.07 percent. On the other hand, the rural poor have little benefit from the Pre-Employment Card Program.

The growth of Non-Agric Urban High is almost the same as that of employers in agriculture. This implies that the upper economic community (in urban and rural areas) indirectly also enjoys the impact of pre-employment card assistance. The possibility of the upper economic community getting an impact from the consumption in the form of spending on preemployment card assistance recipients from post-training incentives of IDR 600 thousand slowly for 4 months. Pre-employment card assistance is provided via cash transfer. The PreEmployment Card program can increase community resilience in facing the direct impact of COVID-19.

Pre-employment card policies can stimulate public responses, including support from community members. The most prominent support comes from the community in the form of mutual assistance which provides informal assistance to the poor. Community support for the 
poor and participation of global institutions in the provision of welfare, are able to overcome the limitations of state social policies during times of socio-economic difficulties, especially due to budget constraints. Many high-income countries implement labor market programs such as grants to support enterprises and businesses. This can help them overcome the increasing unemployment rate due to the COVID-19 pandemic.

\section{Benefits and Disadvantages of Pre-Employment Card}

The Pre-Employment Card is a work competency development program and entrepreneurship aimed at job seekers, workers/laborers affected by termination of employment, and/or workers/laborers who require competency improvement, including micro and small business actors. This program aims to reduce unemployment, but the implementation of the PreEmployment Card is currently being accelerated to reduce the economic impact of the Covid19 virus outbreak. The program is designed as a product and packaged to provide value to users while providing value to the private sector.

Based on the National Labor Force Survey (Sakernas) in August 2020 conducted by the Central Statistics Agency, the majority of Pre-Employment Card recipients think that the preemployment card program improves their work skills. There were as many as 88.9 percent of pre-employment card recipients who completed training stated that the Pre-Employment Card Program improved their job skills. A number of other findings are that the majority of PreEmployment Card recipients are male (58 percent), live in urban areas ( 76 percent), are young, and have high school education and above by 91 percent (Coordinating Ministry for Economic Affairs, 2020).

The main reasons for participants to join the program are to improve their work skills (48 percent) and seek incentives (27 percent) from the population aged 18 years and over. Another finding is that the Pre-Employment Card incentives are generally used to meet daily needs (81 percent), savings (33 percent), and are used for business capital (23 percent). Pre-employment Card recipients come from 34 provinces throughout Indonesia, with the most recipients in West Java (16 percent), followed by DKI Jakarta (10 percent) and East Java (9.8 percent). The province with the least recipients was West Papua ( 0.08 percent), followed by Gorontalo ( 0.37 percent) and Papua ( 0.46 percent).

The August 2020 Sakernas has a sample size of 30 thousand census blocks or about 300 thousand households spread across all regencies/cities throughout Indonesia. Unlike the previous survey, the 2020 survey included several questions related to the impact of the Covid19 pandemic and the social assistance programs implemented by the government.

In addition, to providing information on the success of the Pre-Employment Card Program, this survey also highlights the importance of more massive information dissemination efforts in Eastern Indonesia, particularly Papua and West Papua. The Pre-Employment Card is a very 
young program. When Sakernas was implemented in August 2020, the program had only been effective for 2 months. The results of Sakernas 2020 are very important as material for program evaluation. Sakernas confirmed the positive impact of the Pre-Employment Program in improving job skills. Responding to the findings of Sakernas, the Executive Director of the Pre-Employment Card Program Management explained their seriousness in maintaining the quality of training in the Pre-Employment Card ecosystem so that the results can equip participants' skills.

The Pre-Employment Card Program is a form of collaboration between the government and the private sector in serving the community, to create superior human resources. All Indonesian citizens aged 18 years and over and not currently attending formal education may apply. To respond to the impact of the COVID-19 pandemic, the Pre-Employment Card Program will temporarily prioritize laid-off workers/laborers as well as micro and small business actors who are affected by their livelihoods.

By implementing the 2020 Pre-Employment Card Program, this aims to reduce the large impact of the Covid-19 pandemic on the Indonesian economy, the government hopes to provide benefits and solutions in:

a. Help reduce training costs borne by workers and companies.

b. Able to reduce costs in finding information about training

c. Reducing mismatch between the workforce and the company

d. Complementary to formal education

The following are some of the terms and benefits of registering for the Pre-Employment Card Program:

- The Pre-Employment Card Program is a training program funded by the government.

- Everyone who is 18 years old and above and not in school/college can apply.

- After completing the training, your participants will get incentives in the form of fees every month. The total obtained is IDR 3,550,000 with training costs of IDR 1 million, post-training incentives of IDR 600 thousand per month for 4 and survey filling incentives of IDR 150 thousand.

People who cannot register themselves as participants of the Pre-Employment Card Program are:

- State officials

- Leaders and Members of the Regional House of Representatives

- State Civil Apparatus

- Indonesian National Army Soldiers 
International Journal of Innovation, Creativity and Change. www.ijicc.net

Volume 15, Issue 10, 2021

- Member of the Indonesian National Police

- Village head and village officials

- Directors, Commissioners, and Supervisory Boards in state-owned enterprises or regional-owned enterprises.

The government needs to improve governance in the recruitment process for Pre-Employment Card participants. Improvements need to be made after the findings by the Corruption Eradication Commission (KPK, 2020). There are four aspects highlighted by the KPK, namely problems in the registration process, partnerships with digital platforms, training materials to program implementation. The Pre-Employment Card program was deemed not to be on target, so the government revised the Presidential Regulation by issuing Presidential Regulation Number 76 of 2020. The revised Presidential Regulation aims to ensure that the PreEmployment Card is right on target and effective. This new Presidential Regulation is part of the government's commitment to always strengthen and improve program quality.

\section{Conclusion}

1. The government's budget allocation for the Pre-Employment Card Program accounted as much IDR 30.0 trillion (US\$ 2.065 billion) was able to increase Indonesia's Economic Growth by 0.23 percent. Economic development is closely related to the development of the employment opportunities provisions, income distribution, and output produced level. In economic development point of view, the relationships and interrelationships amongst economic sectors will always occur. In other words, every sector of the economy influences and is interdependent with one to another. Several sectors that had high growth due to the allocation of the Pre-Employment Card Program occurred in the Government Services Sector at 0.72 percent, Food Crops Sector (0.67 percent), Restaurant Sector (0.41 percent), Livestock Sector ( 0.37 percent), Other Services Sector ( 0.36 percent), Fishery Sector $(0.28$ percent) and Electricity-Gas-Water Sector (0.28 percent).

2. The budget allocation for the Pre-Employment Card Program as much IDR 30.0 trillion (US $\$ 2.065$ billion), is able to increase people's income by 0.53 percent. Household sectors in urban areas experienced a large increase in income. Those with high incomes, such as Non-Agric Urban Low 0.27 percent and Non-Agric Urban High 0.07 percent, however, mostly enjoy the impact in urban areas. On the other hand, the rural poor have more little benefit from the Pre-Employment Card Program.

3. The Pre-Employment Card Program can improve job skills. There were as many as 88.9 percent of pre-employment card recipients who completed training stated that the PreEmployment Card Program improved their work skills. A number of other findings are that the majority of Pre-Employment Card recipients are categorized as male (58 percent), live in urban areas (76 percent), young and have high school education, and have a higher 
education (91 percent). However, the Pre-Employment Card Program is considered to be in unappropriated target, so that the government needs to revise the Presidential Regulation by issuing Presidential Regulation Number 76 of 2020. This revision aims to ensure that the Pre-Employment Card is right on target and working effectively. This new Presidential Regulation also is a part of the government's commitment to always strengthen and improve program quality.

\section{Policy Recommendation}

To expand the Pre-Employment Card Program, it is important for the government to consider that vulnerable individuals and households have also to receive this kind of assistance, so that the program is right on target. The limited administrative capacity in determining the eligibility criteria for aid recipients must be addressed quickly and appropriately. Cash transfers to formal and informal workers require targeting due to government financial constraints.

The social safety net policy during the COVID-19 pandemic has influenced the making and implementation of government policies. Within the scope of policy, the Pre-Employment Card Program is an important part of the government's policy process to demonstrate government action in overcoming problems and helping communities affected by the pandemic. However, with the various problems that arise from the social safety net policy, it is clear that the government itself as the executor is still unable to distribute Pre-Employment Cards in accordance with the provisions.

In addition, several policies resulting from socio-economic impacts that create a social safety net show that the policies made by the government are not effective yet in reducing the number of COVID-19 cases. This is because the type of policy is more top-down. Communities become the target group of policies and are less acceptable to policy makers. Actually, in the case of handling COVID-19 in Indonesia, the community can be a determinant of the government success or failure in facing COVID-19.

\section{ACKNOWLEDGEMENT}

The researchers thank to Policy Development Center, Ministry of Manpower for the kindly support in conducting this research. 
International Journal of Innovation, Creativity and Change. www.ijicc.net Volume 15, Issue 10, 2021

\section{REFERENCES}

Abdoul-Azize, H. T., and Gamil, R. E. (2021). Social Protection as a Key Tool in Crisis Management: Learnt Lessons. Global Social Welfare 8, 107-116.

Abidin, M. Z. (2021). Pemulihan Ekonomi Nasional Pada Masa Pandemi Covid-19: Analisis Produktivitas Tenaga Kerja Sektor Pertanian. Jurnal Perbendaharaan, Keuangan Negara Dan Kebijakan Publik, 6(2), 117-138.

Al-Fatih, S., Ahsany, F., and Alamsyah, A. F. (2020). Legal Protection of Labor Rights During the Coronavirus Disease 2019 (Covid-19) Pandemic. Jurnal Pembaharuan Hukum, $7(2), 100-115$.

Andriani, H. (2020). Effectiveness of Large-Scale Social Restrictions (PSBB) toward the New Normal Era during COVID-19 Outbreak: a Mini Policy Review. Journal od Indonesian Health Policy and Administratio, 5(2), 61-65.

Gerard, F., Imbert, C., and Orkin, K. (2020). Social protection response to the COVID-19 crisis: options for developing countries. Oxford Review of Economic Policy, 36 (Issue 1), 281-296.

Halimatussadiah, A., Cesarina, A., Siregar, A. A., Hanum, C., Wisana, D., Rahardi, F.and Kurniawan, R. (2020). Thinking Ahead: Indonesia's Agenda on Sustainable Recovery from COVID-19 Pandemic. Institute for Economic and Social Research Faculty of Economics and Business, Universitas Indonesia (LPEM FEB UI) and Ministry of National Development Planning/National Development Planning Agency (BAPPENAS).

Hanna, R., and Olken, B. A. (2018). Universal Basic Incomes versus Targeted Transfers: AntiPoverty Programs in Developing Countries. Journal of Economic Perspectives, 32(4), 201-226.

Hendrianto, S. (2020). Constitutionalized But Not Constitute: The Case of Right to Social Security in Indonesia. Constitutional Review, 6(2), 241-281.

Hidayat, W. W., Soehardi, Prasetyo, E. T. and Husadha, C. (2021). Implications of Covid-19 Pandemic on MSMEs to Economy, Society: Case in the Country of Indonesia. Systematic Review Pharmacy, 12(4), 71-78. 
International Journal of Innovation, Creativity and Change. www.ijicc.net Volume 15, Issue 10, 2021

International Labour Organization. (2021). Skills development in the time of COVID-19: Taking stock of the initial responses in technical and vocational education and training. International Labour Organization and World Bank 2021.

Israhadi, E. I. (2020). The Social Impact of Force Majeure and The consequences of the Determination of the Covid 19 Disaster Status on Learning the Manpower Law. Journal of Social Studies Education Research, 11 (4), 28-51.

Ivanka, N. (2020). Large-Scale Social Restrictions: What's Next? The Indonesian Journal of International Clinical Legal Education. The Indonesian Journal of International Clinical Legal Education, 2(2), 201-214.

Kementerian Koordinator Bidang Perekonomian Republik Indonesia (2020) Survei Angkatan Kerja Nasional BPS 2020 Ungkap Program Kartu Prakerja Tingkatkan Keterampilan Kerja Penerima. Jakarta 2020.

Köhler, T., and Bhorat, H. (2020). Social Protection, and the Labour Market in South Africa: Are social grants being Targeted at the most Vulnerable? University of Cape Town: Development Policy Research Unit Working.

Komisi Pemberantasan Korupsi (2020). Kajian Komisi Pemberantasan Korupsi Terhadap Program Kartu Prakerja. Direktorat Litbang Hasil Kajian Program Kartu Prakerja. Jakarta 2020.

Kurnianingsih, F., Mahadiansar, M., and Setiawan, R. (2020). Implementation Processes of Social Protection Policy in Indonesia: Study of Prakerja Card Program. Journal of Governance and Public Policy, 7(3), 247-259.

Lord, P. (2020). Incentivising employment during the COVID-19 Pandemic. The Theory And Practice of Legislation, 8 (3), 355-372.

Lu, Q., Cai, Z., Chen, B., and Liu, T. (2020). Social Policy Responses to the Covid-19 Crisis in. International Journal of Environmental Research an Public Health, 1-14. doi:10.3390/ijerph17165896

Mahy, P. (2020). Covid-19 and Labour Law: Indonesia. Italian Labour Law e-Journal, 13(1), $1-10$.

Masduki. (2020). Blunders of Government Communication: The Political Economy of Covid19 Communication Policy in Indonesia. Blunders of Government Communication, 24(2), 97-111. 
International Journal of Innovation, Creativity and Change. www.ijicc.net Volume 15, Issue 10, 2021

Michalopoulos, C. (2001). Sustained Employment and Earnings Growth: New Experimental Evidence on Financial Work Incentives and Pre-Employment Services. The Urban Institute Press .

Muhafidin, D. (2021). Analysis of Government Policies in Treating Work Termination Due to COVID-19 Pandemic. Journal of Futures Studies, 4(1), 27-39.

Nugroho, A. A., and Azmi, I. F. (2021). Alleviating Society's Economic Crisis: Narrative Policy on Social Safety Nets Policy Process During Covid-19 Pandemic. Policy \& Governance Review , 5(2), 113-127.

Predianto, T., and Khoirurrosyid, K. (2020). Mengkaji Upaya Pemerintah Melalui Program Kartu Prakerja dalam Perspektif Pemberdayaan di Masa Pandemi Covid-19. Gorontalo Journal of Government and Political Studies, 3(2), 115-127.

Roziqin, A., Mas'udi, S. Y., and Sihidi, I. T. (2021). An analysis of Indonesian government policies against COVID-19. Public Administration and Policy, 24(1), 92-107.

Sparrow, R., Dartanto, T., and Hartwig, R. (2020). Indonesia Under the New Normal: Challenges and the Way Ahead. Bulletin of Indonesian Economic Studies, 56(3), 269299.

Sumarto, M., and Ferdiansyah, F. (2021). Indonesia's Social Policy Response to Covid-19: Targeted Social Protection under Budget Constraints. CRC 1342 Global Dynamics of Social Policy.

Tedjakusuma, A. P., and Rudenko, S. (2021). How Countries Deal with the Covid-19 Pandemic: A Case Study of Indonesia and Slovakia. Advances in Economics, Business and Management Research, 180, 103-111.

Vaziralli, S. (2021, July). A social protection response to COVID-19 in developing countries. International Growth Centre.

World Bank. (2020). Indonesia Economic Prospects The long Road to recovery. worldbank.org/iep.

Zubaidia, N., Pratama, R. G., and Al-Fatih, S. (2020). Legal Perspective on Effectiveness of Pre-Work Cards for Indonesian People. Jurnal Bestuur, 8(1), 9-18. 